\title{
Effective Direct Vocabulary Instruction to Meet the Focus of the Common Core Standards
}

\author{
Ashlie Jack ${ }^{*}$ \\ Wichita State University, 1845 Fairmount, Campus Box 28, Wichita, KS 67260, United States
}

\begin{abstract}
This article will examine the eight research-based characteristics of effective vocabulary instruction adapted from Building Academic Vocabulary by Robert Marzano (2004). This article will serve as a resource for educators to determine the most effective direct vocabulary approaches to utilize in their classroom as they address vocabulary instruction as outlined in the Common Core State Standards.
\end{abstract}

Keywords: Academic vocabulary, effective vocabulary instruction.

\section{INTRODUCTION}

The implementation of the Common Core State Standards for English Language Arts (CCSS-ELA) has brought a new focus to content area teaching at the K-12 level. All teachers are being asked to integrate reading, writing, speaking, listening, and the effective use of language as a focus of their teaching within their designated discipline. The focus of the English Language Arts (ELA) standards is to help ensure that all students are college and career ready in literacy no later than the end of their high school career.

One specific focus of these standards is the teaching of vocabulary knowledge in all content areas. The key is constructing rich and flexible word knowledge in each discipline; word knowledge that is referred to as academic vocabulary. The focus of academic vocabulary instruction in all disciplines is imperative in order for a student to successfully employ literacy skills in that specific content area. In the CCSS-ELA standards, there are four specific standards (Reading Standard 4; and Language Standard 4, 5, and 6) that speak to the need to increase a student's reading, writing, speaking, and listening vocabularies to support reading comprehension. These standards emphasize 1) interpreting words or phrases; 2) determining or clarifying the meaning of unknown and multiple-meaning words and phrases; 3) understanding figurative language, word relationships, and nuances in word meanings; and 4) acquire and utilize a range of general academic and domain specific words (National Governor's Association Center for Best Practices \& Council of Chief State School Officers, 2010).

Effective P-12 teachers understand the need to stress vocabulary instruction, but at the same time know that it can be challenging and demanding of the time that they have with their students. There is a wide variety of instructional

*Address correspondence to this author at the Wichita State University, 1845 Fairmount, Campus Box 28, Wichita, KS 67260, United States; Tel: 316-978-3589; Fax: 316-978-6935;

E-mail: ashlie.jack@wichita.edu strategies being offered and many teachers have gathered a plethora of resources. But the question is, how do you know the vocabulary strategy or resource that you are utilizing is effective in addressing the vocabulary standards of the CCSS-ELA?

\section{COMPONENTS OF EFFECTIVE DIRECT VOCABU- LARY INSTRUCTION}

Robert Marzano (2004) developed a list of eight research-based characteristics of vocabulary instruction. These characteristics provide a guide for an educator at the early levels of literacy instruction to the middle/secondary level in determining how to choose the right strategy or instructional activity to increase their students' vocabulary knowledge whether they are discussing the solar system in science or a novel during read loud time.

\section{Effective Vocabulary Instruction Does Not Rely on Definitions}

The goal of vocabulary instruction should be developing word consciousness. Individuals who are word conscious are aware and interested in words and word meanings (Anderson \& Nagy, 1992; Graves \& Watts-Taffe, 2002) and notice when and how new words are used in context (Manzo \& Manzo, 2008). Word consciousness is evident in a study conducted during Ms. Barker's kindergarten classroom as she and her students explored the weather outside their classroom door, and while Ms. Riva's fourth graders conducted their morning meeting time as a whole group (Lane \& Allen, 2010). The learning in both of these classrooms engaged the student in deeper levels of processing through incidental word learning approaches that were planned by the classroom teacher. Students in these classrooms were not required to look up definitions in the dictionary or to memorize definitions. Instead a student began the learning process by using terms that they were familiar with to describe the weather or their classmate. The teacher then increased his/her knowledge level by using synonyms of the student's chosen word to describe the weather or classmate and provided the student with multiple 
exposure to the new choice of terminology. This exposure focused on the context of the word; the application of the word's meaning in real-life learning situations; and developed each student's awareness of the word and how to appropriately use it in context. This approach to learning new vocabulary words represents instruction that does not rely on the memorization of definitions, but focuses on the development of a student who is word conscious as they have the ability to utilize and understand more sophisticated terminology during reading, writing, speaking, and listening as content is discussed.

\section{Students Must Represent their Knowledge of Words in Linguistic and Nonlinguistic Ways}

This characteristic of effective direct vocabulary instruction focuses on the implementation of imagery-based representations, such as drawings and graphic organizers allowing the student to verbally, physically, and visually explore the meaning of a word. Brabham et al., (2012) explored such strategies when students were engaged in the use of concept egg charts (Fig. 1), semantic word feature analysis charts (Fig. 2), and semantic word gradient charts (Fig. 3) as a visual representation of their verbal interactions. This imagery-based approach allows a student the opportunity to focus on words that they know; learn new words for known concepts; add new words to build new concepts; and clarify and enrich the meaning of known words. These imagery-based representations are powerful brain-based strategies that increase comprehension and retention of vocabulary words.

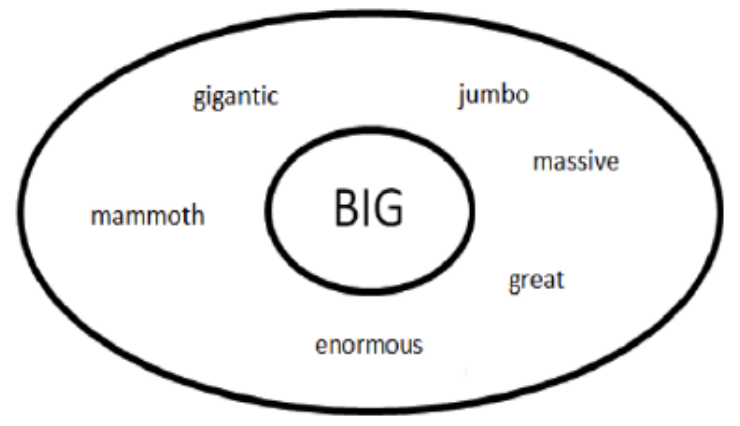

Fig. (1). Vocabulary concept egg chart. (Source: www.google.com)

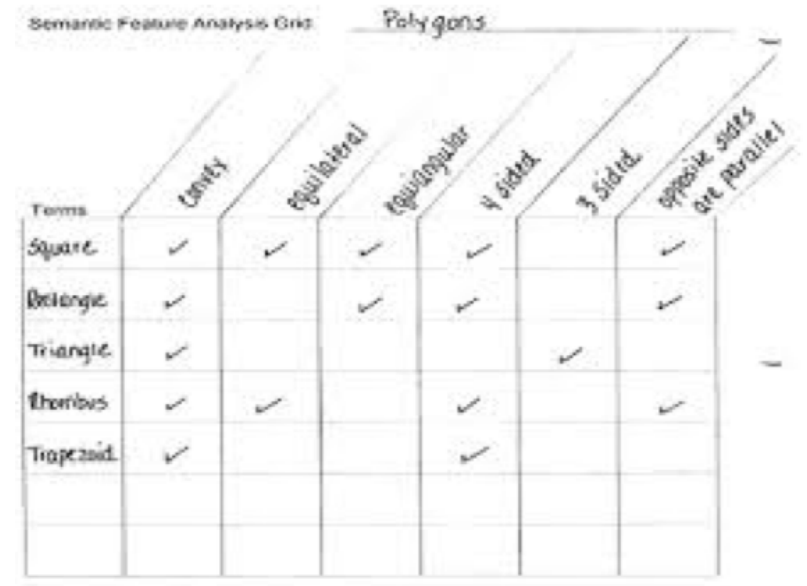

Fig. (2). Vocabulary semantic word feature analysis chart. (Source: http://ohiorc.org/adlit/inperspective/issue/2009-02/article/vignette3.aspx)

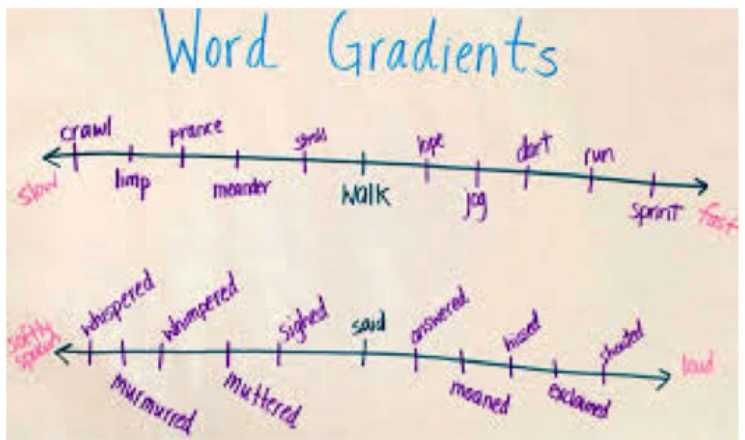

Fig. (3). Vocabulary semantic word gradient chart. (Source: https://litlearnact.wordpress.com/tag/word-gradients)

\section{Effective Vocabulary Instruction Involves the Gradual Shaping of Word Meanings through Multiple Exposures}

To gain a comprehensive understanding vs. a surface understanding of a vocabulary word, repeated and varied exposures are needed. This approach to vocabulary instruction can be applied through the use of online reading where a student has immediate access to pronunciation of the word and internet search engine access to the definition and discussion of the term (Ebner \& Ehri, 2013). Repetitious exposure can also occur during teacher-led instruction on specific science or social studies concepts. The key is ensuring that these multiple encounters allow the student to make connections to their prior knowledge and experiences (Armbruster et al., 2001) through the use of written, visual, and oral modalities as evident in a study conducted in a fifthgrade social studies classroom (Jack, 2011, 2012-2013). Students in this content literacy-based classroom were given the opportunity to reflect on both academic knowledge and personal transactions with the word and its definition through written, visual, and oral response venues. Students acquired and applied their academic vocabulary knowledge in reader response journals (written and/or visual response) (Fig. 4 and 5) and during authentic discussions (oral response) within a classroom where each student defended, justified, and communicated their ideas on the academic vocabulary being studied (Fig. 6). The utilization of these response options within this learning community afforded each student the opportunity to exchange with peers their own personal thoughts, connections, and understanding of the academic vocabulary presented in the text leading to a deeper understanding of the word.

\section{Teaching Word Parts Enhances Students' Understanding of Terms}

The logic behind this characteristic of direct instruction is that knowledge of roots and affixes enables a student to determine the meaning of unknown words. Words parts require a student to use word solving strategies. As noted in the CCSS-ELA standards, word solving happens through the use of context clues, word parts or morphology, and resources. Teachers need to utilize interactive read-aloud of narrative and informational text that include vocabulary terms focusing on prefixes, suffixes, roots, and bases. The teacher must pause and use a think-aloud approach to model how word solving works with the various word parts (Fisher $\&$ Frey, 2014). During the think-aloud, teachers can model to students part-to-whole (relating the meaning of part of the 
word to the word's overall meaning); parts-to-whole (using the meanings of multiple parts to relate to the meaning of the whole word); analogy (analyzing what the prefix of the word means based on what the same prefix means in other words); and whole-to-part (defining the whole word and then using the meaning of part of the word such as the prefix to add to or confirm this meaning) problem solving as outlined in the study conducted by Pacheco \& Goodwin (2013) that analyzed these approaches first found by Anglin (1993).

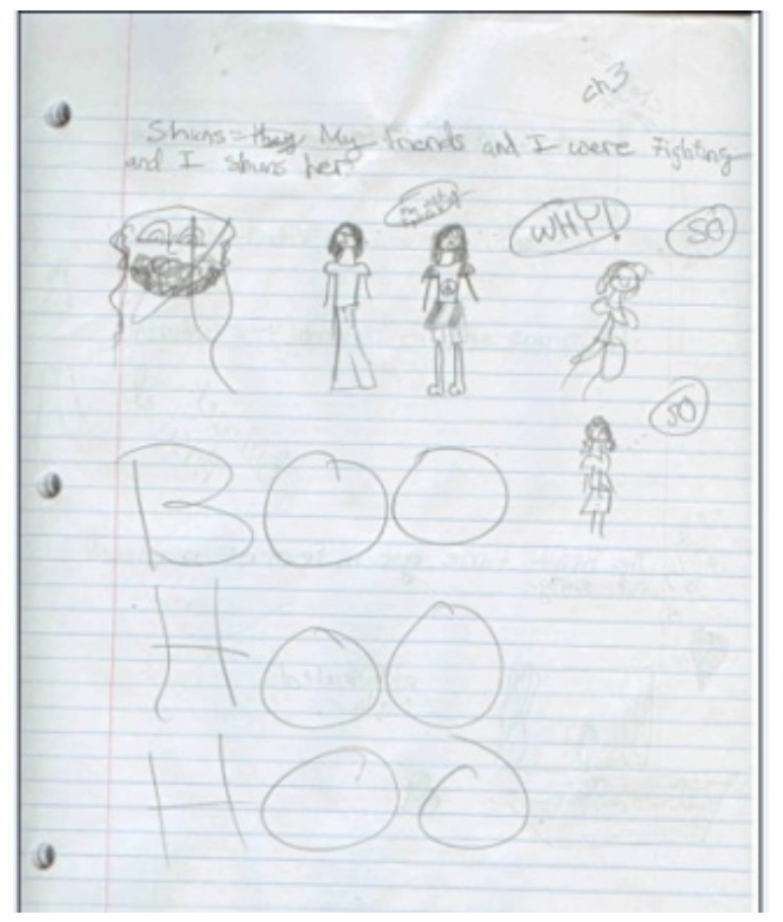

Fig. (4). Written vocabulary reader response journal entry. (Source: (Jack, 2011))

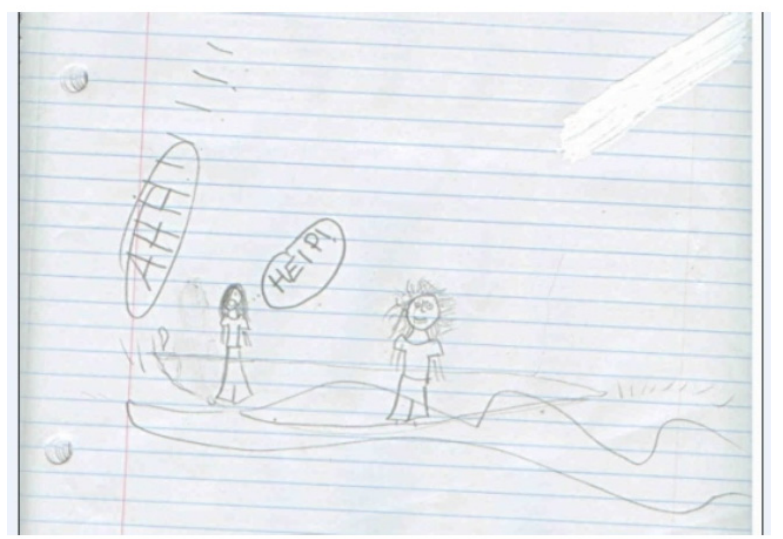

Fig. (5). Visual vocabulary reader response journal entry. (Source: (Jack, 2011))

\section{Different Types of Words Require Different Types of Instruction}

The instruction or activity that a teacher chooses to employ during vocabulary instruction needs to focus on the semantic features of the word. Several experimental studies have isolated and tested the effects of semantic categories of words for vocabulary instruction (Beck et al., 2002;
Stahl et al., 1992) and determined that instruction that features the key semantic features of words that positively affect student learning of the words. Marzano (2004) suggested that vocabulary instruction that is effective and efficient should take advantage of semantic clusters that make up the language. This instructional approach, evident in the use of semantic gradients (Reading Rockets, n.d.), will allow a student to increase their rate of learning new concepts by associating the new words to known concepts and words.

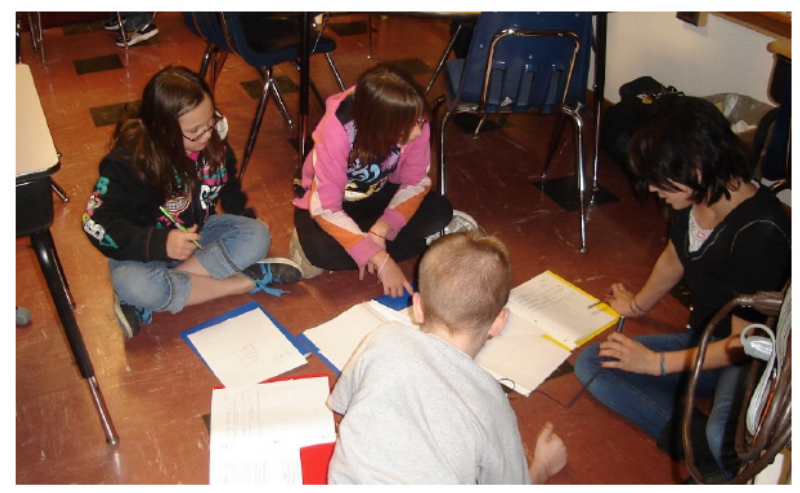

Fig. (6). Authentic discussion of academic vocabulary. (Source: (Jack, 2011))

\section{Students should Discuss the Terms they are Learning}

The likelihood that a student will retain the knowledge of a new term will increase if given the opportunity to interact with other classmates or the teacher in a discussion about the word. For instance, a teacher-led conversation can support a student's vocabulary growth when the teacher takes a simple term the student is using in their written or oral language and utilizes more sophisticated terminology that relates to the term (Dashiell \& DeBruin-Parecki, 2014; Lane \& Allen, 2010). This cognitively interesting word will pique the student's interest and a further discussion on this new term through open-ended questions by the teacher can lead to the student's awareness and interest in the word and its meaning - word consciousness. Oral conversations also allow a student to convert the word and their understanding of the term into their own words. It also allows them the opportunity to view the word and its meaning from different perspectives. Discussions can lead to a deeper understanding of the new terminology.

\section{Students should Play with Words}

Active interaction with the word is crucial for the student to embrace the new terminology beyond a surface level understanding that only allows them to be successful on an exam. There are a variety of avenues in creating this interactive learning through the use of word activities and graphic organizers. A classroom teacher can begin by implementing the effective vocabulary activities listed in the previous six research-based characteristics of vocabulary instruction discussed in this article or utilize one of the resources listed in Table $\mathbf{1}$ to determine an effective vocabulary strategy. The goal is to provide the students with interactive experiences that are challenging and enjoyable yet meet their academic vocabulary needs. 
Table 1. Resources for interactive vocabulary activities*.

Antonacci, P.A., O’Callaghan, C.M., and Berkowitz, E. (2015). Developing content area literacy (2 ${ }^{\text {nd }}$ ed.) Thousand Oaks, CA: Sage.

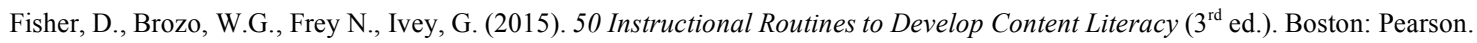

McLaughlin, M. (2015). Content area reading: Teaching and learning for college and career readiness. Boston: Pearson.

Norton, T., \& Jackson-Land, B.L. (2011). 50 literacy strategies for beginning teachers, 1-8 ( $3^{\text {rd }}$ ed). Upper Saddle River, NJ: Merrill Prentice Hall.

Tompkins, G. E., \& Blanchflied, C. (2004). (eds). Teaching vocabulary: 50 creative strategies, grades K-12. Upper Saddle River, N.J.: Merrill Prentice Hall.

Wilfong, L.G. (2013). Vocabulary strategies that work: Do this-not that!. New York, N.Y.: Routledge.

*This is not an exclusive list of the only resources available. These five resources are a starting point for any classroom teacher.

\section{Instruction should Focus on Terms that have a High Probability of Enhancing Academic Success}

Content vocabulary must be taught within the context of building knowledge (Nagy, 2005) because word meanings do not exist in isolation. A teacher must first determine what words are important for their students' success in a unit followed by the direct instructional approaches that will be utilized to actively engage the student in understanding the new terms. The teacher should focus on the six-step process of vocabulary instruction based on research and theory: Step 1) The teacher provides a description, explanation, or example of the new term; Step 2) Students restate the description, explanation, or example of the new term in their own words; Step 3) Students create a picture, symbol, or graphic (nonlinguistic representation) of the term; Step 4) Engage students in activities that help them add to their knowledge of vocabulary terms; Step 5) Periodically, students are asked to discuss the terms with one another; and Step 6) Involve students, periodically, in games that allow them to play with the terms (Marzano \& Simms, 2013; Marzano \& Pickering, 2005; Marzano, 2004).

\section{CLOSING THOUGHTS}

The emphasis of the CCSS-ELA standards is to teach a student to be a strategic thinker ready to create personal meaning from what they are learning in each of the content areas. One area of focus that all classroom teachers must have in order to accomplish this is effective instruction of academic vocabulary. A student must be involved in intentional instruction that provides them with multiple encounters with words. They must be equipped for success to handle complex text, improve their language skills, and boost their reading comprehension by a teacher who emphasizes effective, direct instructional vocabulary activities or strategies that focus on one or more of Marzano' $\mathrm{s}$ eight research-based characteristics of vocabulary instruction. A student's success in a subject area is directly based on a student's depth of word knowledge within that discipline (National Institute for Literacy, 2007).

\section{CONFLICT OF INTEREST}

The author confirms that this article content has no conflict of interest.

\section{ACKNOWLEDGEMENTS}

Declared none.

\section{REFERENCES}

Anderson, R.C., \& Nagy, W.E. (1992). The vocabulary conundrum. American Educator, 16(4), 14-18, 44-47.

Anglin, J.M. (1993). Vocabulary development: A morphological analysis. In: G.A. Miller, P.C. Wakefield (Eds.), Monographs of the Society for Research in Child Development, 58(10), Serial \#238.

Armbruster, B.B., Lehr, F., Osborn, J., \& Adler, C.R. (2001). Put reading first: The research building blocks for teaching children to read, kindergarten through grade 3. Washington, D.C.: National Institute for Literacy, U.S. Department of Education.

Beck,I., McKeown, M., \& Kucan, L. (2002). Bringing words to life: Robust vocabulary instruction. New York: Guilford.

Brabham, E., Buskit, C., Henderson, S.C., Paleologos, T., \& Baugh, N. (2012). Flooding vocabulary gaps to accelerate word learning. The Reading Teacher, 65(8), 523-533.

Dashiell, J. \& DeBruin-Parecki, A. (2014). Supporting young children's vocabulary growth using F.R.I.E.N.D.S. model. The Reading Teacher, 67(7), 512-516.

Ebner, R.J., \& Ehri, L.C. (2013). Vocabulary learning on the internet: Using a structured think-aloud procedure. Journal of Adolescent \& Adult Literacy, 56(6), 480-489.

Fisher, D, \& Frey, N. (2014). Content area vocabulary learning. The Reading Teacher, 67(8), 504-509.

Graves, M.F., Watts-Taffe, S.M. (2002). The place of word consciousness in research-based vocabulary program. In: A.E. Farstrup \& S.J. Samuels (Eds.). What research has to say about reading instruction ( $3^{\text {rd }}$ ed., pp. 140-165). Newark, DE: International Reading Association.

Jack, A. (2011). Word consciousness and individual application of academic vocabulary through written, oral, and visual response to historical fiction and nonfiction literature in fifth-grade social studies. Doctoral dissertation. Kansas State University. United States.

Jack, A. (2012-2013, Winter). Utilizing Written, visual, and oral response options to develop word consciousness of academic vocabulary. Kansas Journal of Reading, 28, 10-15.

Lane, H.B., \& Allen, S.A. (2010). The vocabulary-rich classroom: Modeling sophisticated word use to promote word consciousness and vocabulary growth. The Reading Teacher 63(5), 362-370.

Manzo, U.C., \& Manzo, A.V. (2008). Teaching vocabulary-learning strategies. Word consciousness, word connection, and word predication. In: A.E. Farstrup \& S.J. Samuels (Eds.). What research has to say about vocabulary instruction (pp. 80-105). Newark, DE: International Reading Association.

Marzano, R.J. (2004). Building background knowledge for academic achievement: Research on what works in schools. Alexandria, VA: Association for Supervision and Curriculum Development.

Marzano, R.J., \& Pickering, D.J. (2005). Building academic vocabulary: Teacher's manual. Alexandria, VA: Association for Supervision and Curriculum Development.

Marzano, R.J., \& Simms, J.A. (2013). Vocabulary for the common core. Bloomington, IN: Marzano Research Laboratory.

Nagy, W.E. (2005). Why vocabulary instruction needs to be long-term and comprehensive. In: E.H. Hiebert \& M.L. Kamil (Eds.), Teaching and learning vocabulary (pp. 27-44). Mahwah, NJ: Erlbaum. 
National Institute for Literacy (2000). National reading panel: Teaching children to read. Washington D.C.: U.S. Department of Health and Human Services.

National Institute for Literacy (2007). What content-area teachers should know about adolescent literacy. Washington D.C.: The National Institute for Child Health and Human Development (NICHD).

National Governors Association Center for Best Practices \& Council of Chief State School Officers. (2010). Common Core State Standards for English language arts and literacy in history/social studies, science, and technical subjects. Washington, DC: Authors.
Pacheco, M.B., \& Goodwin, A.G. (2013). Putting two and two together: Middle school students' morphological problem-solving strategies for unknown words, Journal of Adolescent \& Adult Literacy, 56(7), 541-553.

Reading Rockets. (n.d.). Semantic gradients [Online classroom strategies]. Retrieved from http://www.readingrockets.org/strategies/semantic gradients

Stahl, S.A., Burdge, J., Machuga, M., \& Stecyk, S. (1992). The effects of semantic grouping on learning word meaning. Reading Psychology, 13(1), 19-35.

(C) Ashlie Jack; Licensee Bentham Open.

This is an open access article licensed under the terms of the Creative Commons Attribution Non-Commercial License (http://creativecommons.org/licenses/by-nc/3.0/) which permits unrestricted, non-commercial use, distribution and reproduction in any medium, provided the work is properly cited. 